\title{
Seasonal changes in the functional diversity of bacterioplankton in contrasting coastal environments of the NW Mediterranean
}

\author{
M. Montserrat Sala*, Marta Estrada, Josep M. Gasol \\ Departament de Biologia Marina i Oceanografia, Institut de Ciències del Mar-CMIMA (CSIC), \\ Passeig Marítim de la Barceloneta 37-49, 08003 Barcelona, Spain
}

\begin{abstract}
To understand the seasonal and intersite variations in the functional diversity of coastal bacterioplankton assemblages, their utilization of 31 different carbon sources was analyzed with Biolog-Ecoplates ${ }^{\mathrm{TM}}$ in waters from 3 harbours and 2 oligotrophic coastal environments of the NW Mediterranean. Polymers ( $\alpha$-cyclodextrin and glycogen) and carbohydrates (D-cellobiose and $N$ acetyl-D-glucosamine) were most utilized in the harbours, while carboxylic acids were mainly used in the coastal areas. Seasonal differences in the patterns of carbon source utilization (the so-called 'functional diversity') were investigated in 2 spatially close, but contrasting, coastal stations: the oligotrophic coastal site of Blanes Bay, and the Barcelona inner harbour. The existence of a possible seasonal trend in functional diversity of bacterioplankton in the oligotrophic coastal station, but not in the harbour, suggests that the bacterial assemblage of oligotrophic environments can adapt to changing inputs of nutrients and DOC. In contrast, the low water exchange in the harbour provides a pool of DOC of relatively stable composition throughout the year which could allow few potential bacterial metabolisms to persist. We considered the quantity of substrates used (of all those provided in the Biolog plate) as an index of potential functional diversity. The index calculated for the harbour and the coastal station samples was negatively correlated with chlorophyll a concentration, suggesting that the bacterial assemblages of oligotrophic systems have a higher number of metabolic pathways in order to be able to exploit a wide variety of DOC molecules present at low concentrations.
\end{abstract}

KEY WORDS: Bacterioplankton · Biolog $\cdot$ Coastal carbon · Functional diversity · Carboxylic acids Resale or republication not permitted without written consent of the publisher

\section{INTRODUCTION}

Heterotrophic bacteria play a crucial role in the biogeochemical processes of aquatic ecosystems, since they are the major consumers of dissolved organic matter (DOM), the largest pool of organic carbon in natural waters (Azam 1998). DOM availability and composition strongly influences bacterioplankton activity and phylogenetic diversity (Eiler et al. 2003, Kirchman et al. 2004, Malmstrom et al. 2005) and might influence the functional diversity of the bacterial assemblages.

Data on DOM molecular composition in the ocean are difficult to obtain due to a lack of methods with suitable sensitivity for characterizing DOM in seawater
(Benner 2002). For this reason, work on the characterization (Amon \& Benner 2003, Kramer et al. 2005) and bacterial utilization (Jørgensen et al. 1993, Keil \& Kirchman 1999, Grossart \& Simon 2002, Pérez et al. 2003, Rosenstock et al. 2005, Sannigrahi et al. 2005) of identifiable compounds within the DOM pool has focused mainly on monosaccharide and amino acid analyses. Furthermore, the methodological constraints in the measurement of individual DOM molecule fluxes have led to the application of indirect methods for studying bacterial utilization of DOM compounds, such as the characterization of ectoenzymatic activities (Christian \& Karl 1995, Unanue et al. 1999, Misic et al. 2002, Arnosti et al. 2005), or nutrient addition experi- 
ments (Jørgensen et al. 1993, 2003, Carlson \& Ducklow 1996, Foreman et al. 1998, Church et al. 2000). However, these nutrient addition experiments are timeconsuming and, therefore, the potential amount of carbon sources tested simultaneously is limited. Biolog-Ecoplates are a miniaturized version of these experiments and provide information on the simultaneous utilization of 31 carbon sources. Similar to the addition experiments, the main shortcoming of the utilization of the Biolog microplates for community profiling is the fact that this is a culture-based approach, in which opportunistic bacteria might dominate. Another drawback is that the substrates in the Biolog plate are not necessarily representative of those available in the natural environments (Konopka et al. 1998). This has been improved with the introduction of the BiologEcoplates, which contain a set of carbon sources more relevant for ecological studies (Choi \& Dobbs 1999).

In spite of these shortcomings, Biolog plates have provided useful information on the functional diversity of bacterial communities from soils and sediments (see references in Preston-Mafham et al. 2002), freshwater (Grover \& Chrzanowski 2000, Sinsabaugh \& Foreman 2001, Worm et al. 2001) and marine plankton systems. For example, studies in marine ecosystems have shown (1) that functional diversity was strongly influenced by temperature and salinity in the York River estuary (Schultz \& Ducklow 2000); (2) that there was a lack of relationship between phytoplankton abundance and bacterioplankton functional diversity in Antarctic waters (Sala et al. 2005a), suggesting that bacteria could utilize carbon sources other than freshly released phytoplanktonic DOC in such waters; and (3) that phylogenetic and functional diversity can be uncoupled during blooms of harmful dinoflagellates (Sala et al. 2005b). Additionally, Biolog plates may provide information on the bacterial utilization of dissolved organic nitrogen sources in aquatic environments (Sala et al. 2006), and have been useful for characterizing bacterial isolates from several marine environments (Tan 1997, Tan \& Rüger 1999, Frette et al. 2004).

While the Catalan coast (NW Mediterranean) is relatively oligotrophic, with low nutrient and chlorophyll a (chl a) concentrations, the harbours offer contrasting environments characterized by high nutrient concentrations (Vila \& Masó 2005) and lower water exchange, which generally support high phytoplankton biomass and occasionally harmful algal blooms (Vila et al. 2001). Previous studies indicated a distinct composition of the bacterial assemblage in these contrasting environments, i.e. coastal waters and harbours, in the Catalan Coast (Schauer et al. 2000). A similar study revealed clear seasonal changes in the taxonomic composition of bacterioplankton in the oligotrophic coastal station of Blanes Bay (Schauer et al. 2003). Since changes in composition are often linked to changes in the metabolic potential of the bacterioplankton assemblage (Martínez et al. 1996, Riemann \& Azam 2002, Kirchman et al. 2004), we expect to find differences in the functional diversity of bacterioplankton assemblages of the harbours and coastal waters, and seasonal changes at the Blanes station.

The aims of the present study were (1) to compare the single carbon source utilization profiles (CSUPs) of the surface bacterial assemblages of 5 different sites of the Catalan coast (NW Mediterranean), including harbours and coastal stations, and (2) to examine the seasonal pattern of CSUPs in the Barcelona harbour and the coastal station in Blanes Bay and relate them to environmental factors. We hypothesized that bacterioplankton in the harbours would show a higher utilization of complex carbon sources, perhaps caused by the presence of oil or other waste products from boats, and that, due to the lower water exchange, the bacterial assemblage would be less dynamic than in coastal waters.

\section{MATERIALS AND METHODS}

Sampling. Surface seawater was collected from 5 stations along the Catalan coast (NW Mediterranean): 3 harbours and 2 coastal stations (see Table 1). Seawater was kept in 251 clean plastic carboys and water was transported within $2 \mathrm{~h}$ in the dark to the laboratory.

The Barcelona harbour was sampled 24 times during June 2001 to October 2002. The Tarragona harbour, $100 \mathrm{~km}$ south of Barcelona, was sampled 4 times in June 2001 during a bloom of the dinoflagellate Alexandrium catenella. The Arenys de Mar harbour, $40 \mathrm{~km}$ north of Barcelona, was sampled 6 times during a bloom of Alexandrium minutum in January-February 2002.

The 2 coastal stations Masnou and Blanes were both sampled by boat $400 \mathrm{~m}$ offshore. Waters from the Microbial Observatory of Blanes Bay, $70 \mathrm{~km}$ north of Barcelona, were sampled monthly during January 2003 and December 2004, and 4 additional samples were collected during 2001 and 2002. The Masnou station, $20 \mathrm{~km}$ north of Barcelona was sampled on 2 occasions in April and November 2002.

Water was collected with a bucket at all sites, at approximately 0 to $50 \mathrm{~cm}$ depth. In Blanes, Barcelona harbour and Masnou, water was sampled from a boat while in Arenys de Mar and Tarragona harbours it was collected from the pier.

Environmental parameters. $\mathrm{Chl}$ a concentrations were determined fluorimetrically following Yentsch \& Menzel (1963). Samples between 100 and $150 \mathrm{ml}$ were 
filtered through Whatman GF/F filters. After keeping the filters frozen at $-20^{\circ} \mathrm{C}$ for at least $2 \mathrm{~h}$, pigments were extracted in $6 \mathrm{ml} 90 \%$ acetone in the dark for $24 \mathrm{~h}$. Inorganic nutrient concentrations of soluble reactive phosphorus (SRP), nitrate, nitrite and ammonia were measured according to Grasshoff et al. (1983). Total inorganic nitrogen (TIN) represents the sum of nitrate, nitrite and ammonia. Bacterial numbers were obtained using flow cytometry for the Blanes samples and epifluorescence microscopy for those from the other stations. For flow cytometry, we followed the method of Gasol \& del Giorgio (2000) and for epifluorescence microscopy, a modification of the method of Porter \& Feig (1980) was used. Five ml of seawater fixed with formaldehyde ( $2 \%$ final conc.) were filtered onto $0.2 \mu \mathrm{m}$ black polycarbonate filters and stained with DAPI (0.5 mg ml-1 final conc.) onto $0.2 \mu \mathrm{m}$ black polycarbonate filters. Bacteria on filters were counted under a Zeiss Axioplan epifluorescence microscope.

Biolog plates. Biolog-Ecoplate ${ }^{\mathrm{TM}}$ microplates were used to determine differences in the metabolic potential of the bacterioplankton assemblages following the method of Sala et al. (2005a). Biolog-Ecoplates are 96well microtiter plates containing 31 carbon sources in triplicate. Each well contains the redox dye tetrazolium violet in a dry film together with the carbon source. As the carbon source is oxidized, formazan is formed which can be quantified spectrophotometrically.

Each well was inoculated with $150 \mu \mathrm{l}$ of sample water and the plates were then incubated at room temperature for $6 \mathrm{~d}$. After incubation, absorbance of the plates was measured at a wavelength of $590 \mathrm{~nm}$ using a spectrophotometric microplate reader (ELX800 BIOTEK Instruments).

The utilization of each carbon source was expressed as the average substrate color development (ASCD).
This was calculated after subtracting the mean absorbance of the control wells (without a carbon source) from the absorbance of each well and then calculating the mean absorbance of each substrate of the 3 replicate wells for each substrate. The ASCD was then computed as a percentage of the absorbance of each substrate over the sum of absorbance of all substrates.

Hierarchical cluster analysis. Hierarchical cluster analysis (HCA) was used to detect differences among the patterns of substrate utilization at the 5 stations sampled and also to differentiate the seasonal means of ASCD for each substrate. The program STATISTICA 6.0 with City Block and Ward's method were used in this analysis. Data from HCA were used to construct a similarity dendrogram. Similarity was scaled to $100 \%$.

\section{RESULTS}

\section{Differences between coastal stations and harbours}

Samples from the harbours always showed higher mean values of chl $a$, bacterial abundance and inorganic nutrient concentrations than coastal samples (Table 1). Mean chl a concentrations were 4 times higher in Barcelona than in Blanes; they were especially high in the Arenys de Mar (10.2 $\left.\mathrm{gg} \mathrm{l}^{-1}\right)$ and Tarragona (140.2 $\mathrm{g} \mathrm{I}^{-1}$ ) harbours, since samples had been collected during Alexandrium spp. blooms. Nutrient concentrations of both TIN and SRP were up to 6 times higher in the harbours than at the coastal station.

HCA of the substrate use in the Biolog plates revealed a root discrimination of most of the harbour samples from those of coastal waters (Fig. 1). Samples from coastal waters were separated in 2 main clusters, whereas $82 \%$ of

Table 1. Average properties of the samples used to investigate differences in bacterioplankton functional diversity among the studied areas. Results show mean (coefficient of variation in parentheses). n: number of samples; BACT: heterotrophic bacterial concentration; SRP: soluble reactive phosphorus; DIN: dissolved inorganic nitrogen

\begin{tabular}{|c|c|c|c|c|c|c|c|c|}
\hline Stn & Date & $\mathrm{n}$ & $\begin{array}{c}\text { Temp. } \\
\left({ }^{\circ} \mathrm{C}\right)\end{array}$ & Salinity & $\begin{array}{c}\text { Chl a } \\
\text { conc. }\left(\mathrm{mg} \mathrm{l}^{-1}\right)\end{array}$ & $\begin{array}{c}\text { BACT } \\
\left(\times 10^{6} \mathrm{ml}^{-1}\right)\end{array}$ & $\begin{array}{c}\text { SRP } \\
(\mu \mathrm{M})\end{array}$ & $\begin{array}{l}\text { DIN } \\
(\mu \mathrm{M})\end{array}$ \\
\hline \multicolumn{9}{|l|}{ Harbours } \\
\hline Barcelona & Jun 2001-Oct 2002 & 24 & $\begin{array}{c}18.0 \\
(0.70)\end{array}$ & $\begin{array}{c}37.6 \\
(0.03)\end{array}$ & $\begin{array}{c}4.47 \\
(1.41)\end{array}$ & $\begin{array}{c}2.51 \\
(0.62)\end{array}$ & $\begin{array}{c}0.97 \\
(0.81)\end{array}$ & $\begin{array}{l}14.45 \\
(0.86)\end{array}$ \\
\hline Arenys de Mar & Jan-Feb 2002 & 6 & $\begin{array}{c}12.5 \\
(0.01)\end{array}$ & - & $\begin{array}{l}10.15 \\
(0.37)\end{array}$ & $\begin{array}{c}1.72 \\
(0.58)\end{array}$ & $\begin{array}{c}0.33 \\
(0.72)\end{array}$ & $\begin{array}{l}20.98 \\
(1.99)\end{array}$ \\
\hline Tarragona & Jun 2001 & 4 & $\begin{array}{c}22.5 \\
(0.02)\end{array}$ & $\begin{array}{c}37.5 \\
(0.00)\end{array}$ & $\begin{array}{l}140.2 \\
(1.18)\end{array}$ & $\begin{array}{c}9.81 \\
(0.41)\end{array}$ & $\begin{array}{c}0.40 \\
(1.14)\end{array}$ & $\begin{array}{l}14.41 \\
(0.44)\end{array}$ \\
\hline \multicolumn{9}{|l|}{ Coastal waters } \\
\hline Blanes & $\begin{array}{c}\text { May, Jun, Nov } 2001 \\
\text { Nov } 2002 \\
\text { Jan 2003-Dec } 2004\end{array}$ & 27 & $\begin{array}{c}18.0 \\
(0.25)\end{array}$ & $\begin{array}{c}37.5 \\
(0.02)\end{array}$ & $\begin{array}{c}0.84 \\
(0.81)\end{array}$ & $\begin{array}{c}1.00 \\
(0.30)\end{array}$ & $\begin{array}{c}0.16 \\
(0.25)\end{array}$ & $\begin{array}{l}2.55 \\
(0.9)\end{array}$ \\
\hline Masnou & Apr, Nov 2002 & 2 & - & - & 2.89 & 1.20 & - & - \\
\hline
\end{tabular}




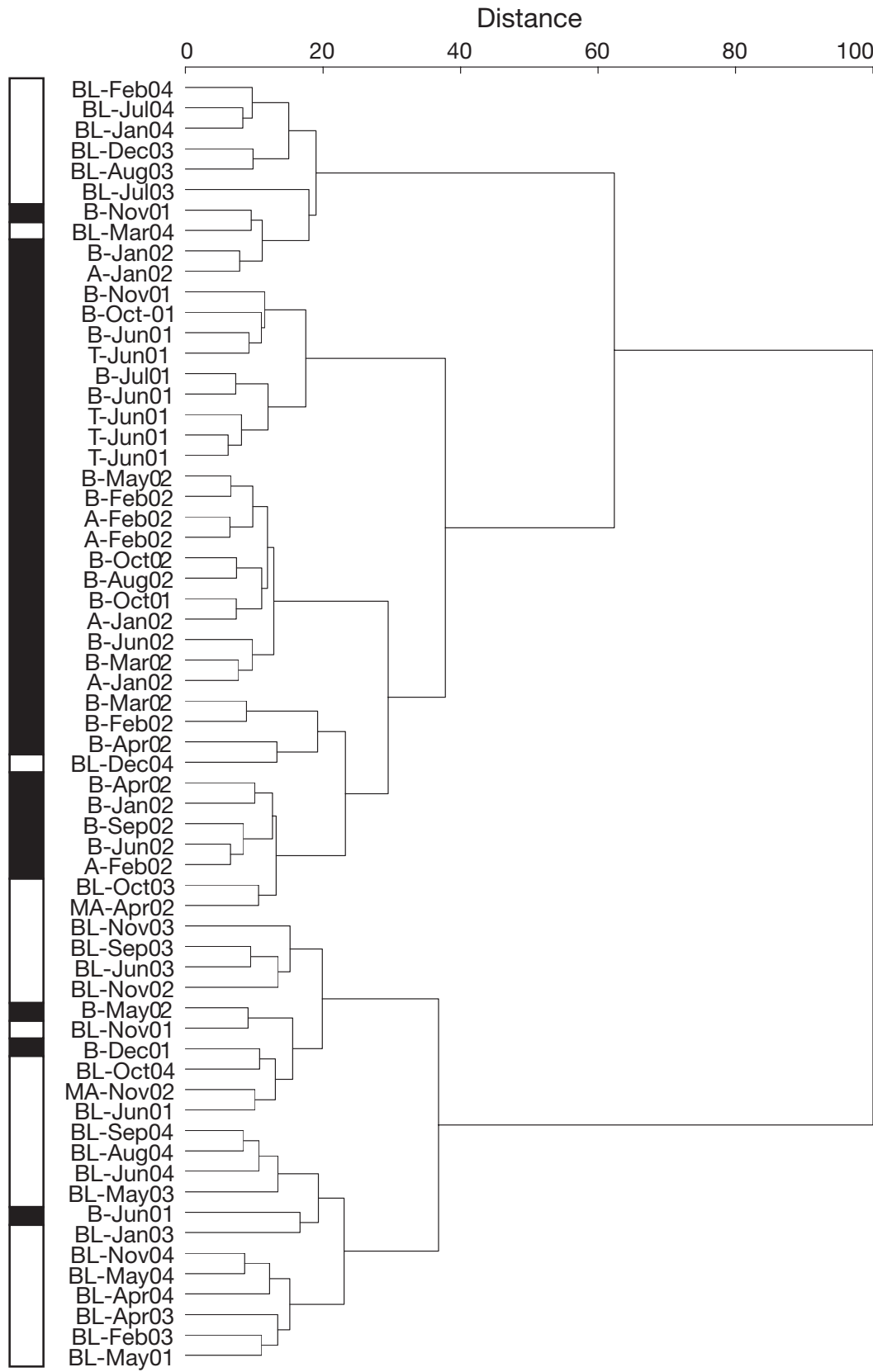

Fig. 1. Hierarchical cluster analysis of the ASCD (average substrate color development) in the Biolog-Ecoplates obtained at 5 stations (3 harbour stations and 2 coastal stations) of the NW Mediterranean coast-B: Barcelona harbour; T: Tarragona harbour; A: Arenys de Mar harbour; BL: Blanes; M: Masnou. The bar shows the origin of the sample-black: harbours; white: coastal stations

amino acid (L-phenylalanine) were used significantly more in the coastal waters than in the harbours $(\mathrm{p}<0.001)$.

\section{Seasonal patterns}

We investigated the seasonal variability at 2 stations, Barcelona harbour and the coastal station of Blanes (Fig. 2), and tested the differences using a 1-way ANOVA and a post-hoc Tukey test after aggregation of the samples in seasons. In Blanes, significant variablility was found for chl a concentration $(F=7.90, \mathrm{p}=0.001)$, with higher concentrations in winter than in summer ( $p=0.002)$, in autumn $(p=0.005)$ and in spring $(\mathrm{p}=0.037)$. TIN also varied significantly among seasons $(F=4.03, \mathrm{p}=0.024)$, and was higher in winter than in summer $(p=0.014)$. This led to substantial differences in the N:P ratio $(F=41.80, \mathrm{p}<0.001)$ between winter (mean $\mathrm{N}: \mathrm{P}=29.5$ ) and summer (mean N:P = 6.2).

In the Barcelona harbour, both inorganic nutrients showed marked differences in concentrations among seasons. SRP concentration $(F=8.866, \mathrm{p}=0.0003)$ was higher in autumm than in summer ( $p=0.004)$ or spring $(p=0.015)$, and in winter than in summer $(p=0.03)$. TIN also exhibited clear differences among seasons $(F=12.94)$, with higher concentrations in winter than in spring $(\mathrm{p}=0.0008)$ or summer ( $p=0.0002)$, and in autumm than in spring $(0.015)$ or summer $(p=$ 0.0016). However, these differences in both inorganic nutrient concentrations led to no significant differences in the N:P ratios of the dissolved pools, which varied between 11.0 in spring and 23.2 in winter.

A statistical comparison of the average values of utilization of each carbon source for each season is shown in Fig. 3. Coastal samples clustered mainly according to the sampling site. Samples from Barcelona clustered more closely than

harbour samples could be found in one single branch. Several substrates were differentially used in both sampling areas (Table 2). The harbours were characterized by higher ( $t$-test, $\mathrm{p}<0.0001$ ) utilization of 4 substrates, 2 polymers and 2 carbohydrates: $\alpha$-cyclodextrin, D-cellobiose, $N$-acetyl-D-glucosamine and glycogen. In contrast, 4 carboxylic acids, $\gamma$-hydroxybutyric acid, D-glucosaminic acid, D-malic acid and itaconic acid, and 1 those taken off Blanes. A much looser affiliation with the Blanes cluster could be observed in winter.

Seasonal means of the ASCDs of each carbon source in the Biolog-Ecoplate are shown in Fig. 4. In this study, we regarded $2 \%$ absorbance of the total absorbance per plate as the threshold for substrate utilization. In general, we found that a lower number of substrates was used in Barcelona harbour (17 to 19), 

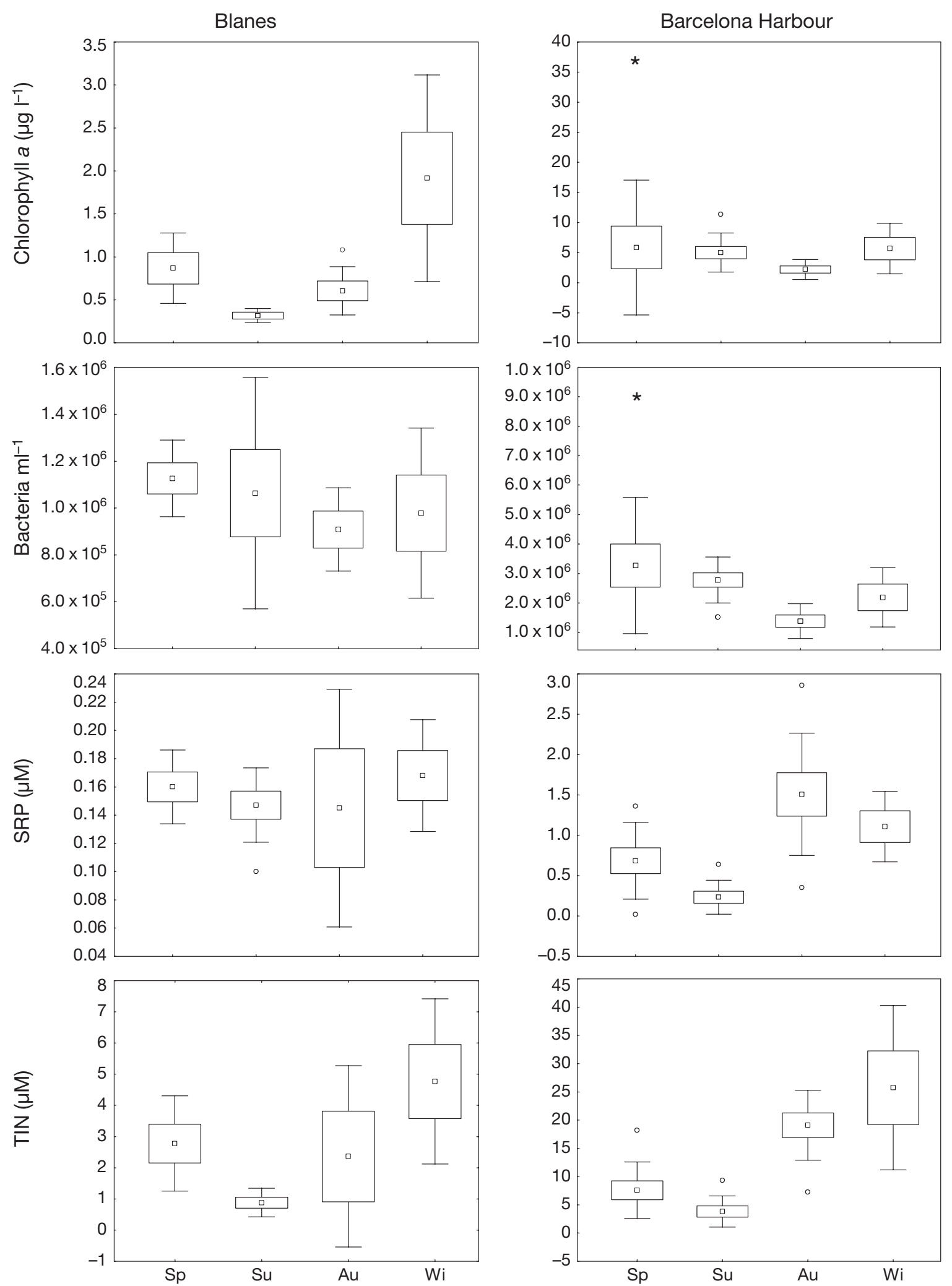

Fig. 2. Distribution of chlorophyll $a$, bacterial abundance, soluble reactive phosphorus (SRP) and total inorganic nitrogen (TIN) concentrations over the 4 seasons (Sp: spring; Su: summer; Au: autumn; Wi: winter). For Barcelona harbour, $\mathrm{n}=5$ to 10 , and for Blanes, $\mathrm{n}=5$ to 7 . Square: mean; Box: standard error; Whisker: \pm SD; Circles: outliers (values higher/lower than: the upper/lower value of the box +1.5 times the height of the box); asterisks: extremes (values higher/lower than: the upper/lower value of the box +3 times the height of the box) 


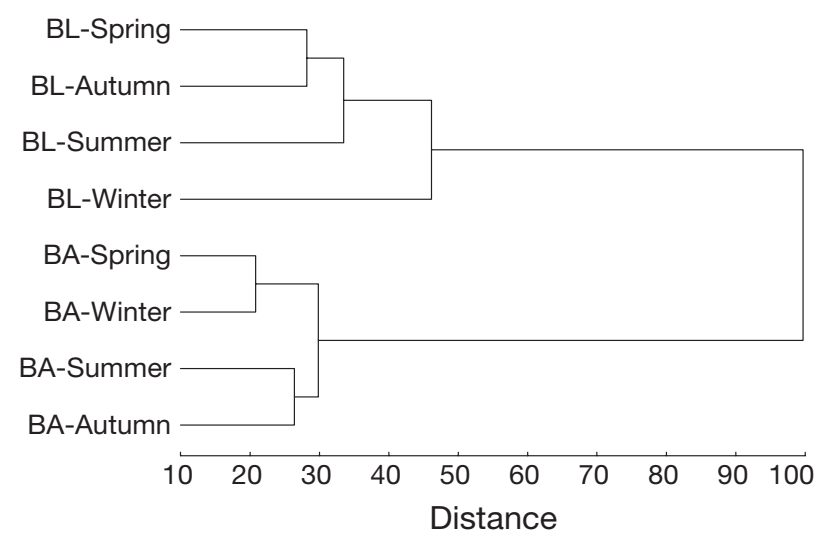

Fig. 3. Hierarchical cluster analysis of the mean ASCD for each substrate, season and station. BA: Barcelona harbour; BL: Blanes
Table 2. Differences in substrate utilization in samples collected at the 2 coastal stations and the 3 harbours. $t$-test with: ${ }^{*} \mathrm{p}<0.001,{ }^{* *} \mathrm{p}<0.0001,{ }^{* * *} \mathrm{p}<0.00001$

\begin{tabular}{|c|c|}
\hline Substrate & Category \\
\hline \multicolumn{2}{|l|}{ Coastal waters } \\
\hline$\gamma$-hydroxybutyric acid ${ }^{* *}$ & Carboxylic acid \\
\hline D-glucosaminic acid ${ }^{* *}$ & Carboxylic acid \\
\hline Malic acid* & Carboxylic acid \\
\hline Itaconic acid ${ }^{*}$ & Carboxylic acid \\
\hline L-phenylalanine* & Amino acid \\
\hline \multicolumn{2}{|l|}{ Harbours } \\
\hline$\alpha$-cyclodextrin ${ }^{* * * *}$ & Polymer \\
\hline D-cellobiose $\mathrm{e}^{* * * *}$ & Carbohydrate \\
\hline $\mathrm{N}$-acetyl-D-glucosamine ${ }^{* * *}$ & Carbohydrate \\
\hline Glycogen $* *$ & Polymer \\
\hline
\end{tabular}

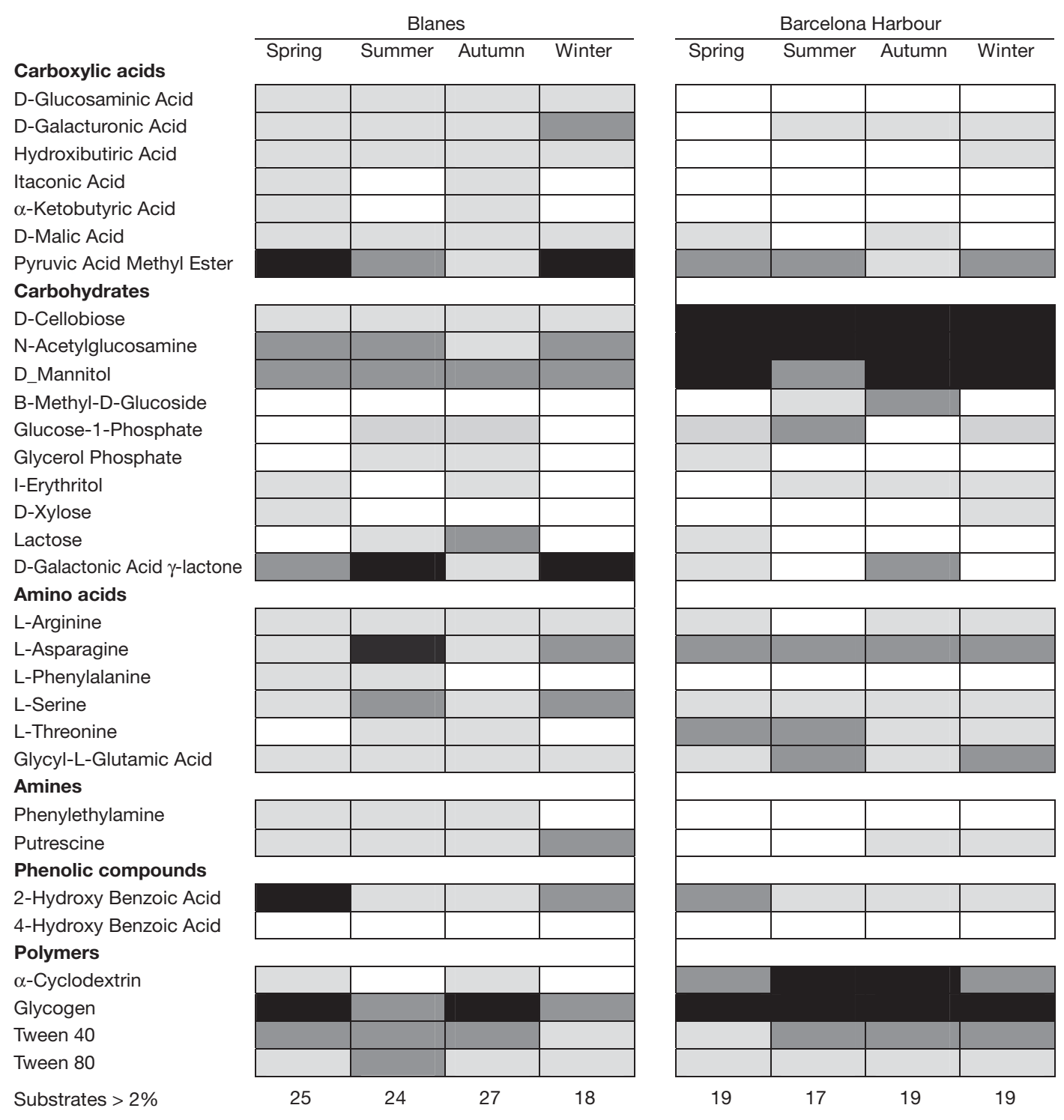

Fig. 4. Mean ASCD for each season for the samples taken at Blanes and in Barcelona Harbour. Shading in the boxes indicates the range of percentage absorbance of the total absorbance of the plate. White: $<2 \%$, light grey: 2 to $4 \%$, dark grey: 4 to $6 \%$, black: $>6 \%$. Below each column, the number of substrates with $>2 \%$ absorbance for each season is indicated 
whereas in Blanes this value was significantly higher (18 to $27, \mathrm{p}<0.05$ ). The number of utilized substrates varied considerably in Blanes, with a lower number in winter (18) compared to the rest of the year (24 to 27).

The breakdown of the percent utilization of the carbon sources into the main categories listed in Fig. 4 showed no significant seasonal trends for substrate use at both sites. However, some differences could be observed for the Blanes station: a higher mean percentage of utilization of amino acids in summer ( $24 \%$ ) than the other seasons (17 to $19 \%$ ) and a lower utilization of polymers in winter $(12 \%)$ than during the rest of the year (17 to $19 \%)$.

\section{DISCUSSION}

\section{Differences between harbours and coastal stations}

Functional diversity, understood in this study as the utilization of single carbon sources in Biolog plates, showed clear differences between harbours and coastal ecosystems. Generally, harbour samples were characterized by a higher utilization of 2 polymers and 2 carbohydrates. The 2 carbohydrates, D-cellobiose and $N$-acetyl-D-glucosamine (NAG), have been shown to be important sources for bacterial growth in aquatic systems (Riemann \& Azam 2002, Sala \& Güde 2004). NAG is a major component of structural polymers in bacteria, algae and zooplankton and fungi, in the form of the homopolymer of NAG, chitin. D-cellobiose is a disaccharide subunit of cellulose and a primary structural component of algae. Both substrates were among the most used in Biolog-Ecoplate samples from western Antarctic seawaters (Sala et al. 2005a). The 2 polymers used mainly in harbours are also carbon substrates likely to be found in nature and probably of autochthonous origin: $\alpha$-cyclodextrin (analog of amylose, a component of starch, the main storage molecule of algae), and glycogen (a storage molecule in animals and bacteria).

In contrast, in coastal waters, the most used carbon sources were carboxylic acids. Carboxylic acids can be considered to be part of the labile pool of organic matter, which is an important carbon source for bacterioplankton in the Mediterranean Sea (Obernosterer et al. 1999) and other marine environments (Pullin et al. 2004). Few studies compare the lability of DOC in harbours and open waters, and only Fry et al. (1996) observed a larger recalcitrant portion of DOC in harbours compared to the DOC released during phytoplankton blooms.

$\mathrm{Chl} a$ and nutrient concentrations in the harbours were often 1 order of magnitude higher than at the coastal stations. Phytoplankton are the main producers of DOC in marine environments, and DOC derived from phytoplankton is efficiently utilized by bacteria
(Jensen 1983, Lancelot 1984). The high inorganic nutrient concentrations, particularly in phosphorus, probably enhance bacterial utilization of carbohydrates and polymers (cellobiose, glycogen, $\alpha$-cyclodextrin and $N$-acetyl-D-glucosamine) in the harbours. The presence of complex molecules in waste products of boats or sewage in the harbours would probably also favour bacteria capable of using polymeric carbon sources. These reported differences in metabolic abilities between the harbours and coastal stations appear to be associated with the differences in phylogenetic composition observed for the bacterial assemblages among these stations (Schauer et al. 2000).

\section{Seasonal patterns}

No clear seasonal patterns of single carbon source utilization were found in Barcelona harbour and the coastal station of Blanes. The mean seasonal values shown in Fig. 3 indicated that samples clustered depending on the sampling site. However, within each cluster, the samples from Barcelona harbour appeared more closely related than the Blanes cluster, with winter being the most loosely associated. In Blanes, winter was characterized by significantly higher chl a and TIN concentrations, leading to higher N:P ratios. The different environment in winter probably led to a bacterial assemblage with distinct functional diversity, with a higher utilization of carboxylic acids and lower use of polymers. In contrast, no seasonal trends could be observed in the samples from the Barcelona harbour for any of the parameters measured. This relatively stable environment corresponds with a less dynamic bacterial community in which only small differences were found in single carbon source utilization among different seasons, i.e. a lower utilization of polymers in spring. In contrast to coastal environments, harbours are characterized by calm waters with low water exchange, probably favoring an environment characterized by low changes in DOC and nutrients. These conditions might select for only a small number of metabolic pathways persisting throughout the year. Grover \& Chrzanowski (2000) found also seasonal trends in the functional diversity of bacteria, analyzed with Biolog plates, in 4 lakes: a higher response to amino and carboxylic acids in colder seasons and strong relative responses to carbohydrates in warm seasons. They related this pattern to seasonal events among phytoplankton.

The number of substrates used in each season and station showed similar trends as the seasonal mean values of ASCD. In Barcelona harbour, the number of substrates used was lower than at Blanes and relatively constant throughout the year. Only the number of sub- 
strates used in winter at Blanes (18) was markedly lower than the annual mean and within the range of the number of substrates used in Barcelona harbour (17 to 19). Similarly, results on bacterial clone libraries constructed for each season (L. Alonso-Sáez et al. unpubl. data) show a lower phylogenetic diversity in winter than during the rest of the year, when $\alpha$-Proteobacteria clearly dominated. These results suggest a possible coupling between functional and phylogenetic diversity in Blanes Bay.

Cottrell \& Kirchman (2000) observed that bacteria of the Bacteroidetes group were related to the utilization of NAG, whereas members of the $\alpha$-Proteobacteria dominate amino acid uptake. The contribution of $\alpha$ Proteobacteria and Bacteroidetes to total bacterial abundance was determined by fluorescent in situ hybridization in the samples from Blanes (L. AlonsoSáez et al. unpubl. data). They found positive correlations, although not significant, between the percentage of $\alpha$-Proteobacteria and the utilization of each of the 6 amino acids in the plate, and between the percentage of Bacteroidetes and utilization of NAG in the Biolog plate.

Both chl $a$ and TIN showed higher concentrations in winter at Blanes, and high concentrations in Barcelona harbour throughout the year, and these were the periods and stations characterized by the utilization of a low number of substrates. We, therefore, investigated the influence of both parameters on the low number of substrates used. Only chlorophyll showed a significant correlation with the number of substrates used (log:log $\mathrm{r}=$ $-0.34, n=43, p=0.026$ ). If we consider the number of substrates used as an estimation of functional diversity, our results suggest a negative relationship between $\mathrm{chl}$ a concentration and bacterial functional diversity. These results support the ecological theory of a high diversity in oligotrophic systems and lower diversity in richer systems (Frontier 1985), although HornerDevine et al. (2003) claim that primary productivity has no clear effects on bacterial phylogenetic richness.

The differences in the number of substrates used among different seasons at Blanes might suggest that the bacterial assemblage in oligotrophic environments is perhaps forced to adapt to the changing inputs of organic matter and nutrients. Therefore, the bacterial assemblages in oligotrophic areas express a higher plasticity in metabolic pathways in order to be able to exploit the changing and limited carbon sources available for growth.

Acknowledgements. This work was supported by the projects BIOHAB (EVK3-CT99-00015), BASICS (EVK3-CT200200078) and PROCAVIR (CTM 2004-04404-C02-01/MAR) and by a CSIC-I3P post-doctoral contract funded by the Fondo Social Europeo to M.M.S. We thank J. Felipe and V. Balagué for their skillful technical assistance, R. Massana for his unpublished results on clone libraries, and J. Pinhassi, C. Pedrós-Alió and 2 anonymous reviewers for their very helpful comments on the manuscript.

\section{LITERATURE CITED}

Amon RMW, Benner R (2003) Combined neutral sugars as indicators of the diagenetic state of dissolved organic matter in the Arctic Ocean. Deep-Sea Res I 50:151-169

Arnosti C, Durkin S, Jeffrey WH (2005) Patterns of extracellular enzyme activities among pelagic marine microbial communities: implications for cycling of dissolved organic carbon. Aquat Microb Ecol 38:135-145

Azam F (1998) Microbial control of oceanic carbon flux: the plot thickens. Science 280:694-696

Benner R (2002) Chemical composition and reactivity. In: Hansell DA, Carlson CA (eds) Biogeochemistry of marine dissolved organic matter. Academic Press, San Diego, CA

Carlson CA, Ducklow HW (1996) Growth of bacterioplankton and consumption of dissolved organic carbon in the Sargasso Sea. Aquat Microb Ecol 10:69-85

Choi KH, Dobbs FC (1999) Comparison of two kinds of Biolog microplates (GN and ECO) in their ability to distinguish among aquatic microbial communities. J Microbiol Methods 36:203-213

Christian JR, Karl DM (1995) Bacterial ectoenzymes in marine waters-activity ratios and temperature responses in 3 oceanographic provinces. Limnol Oceanogr 40:1042-1049

Church MJ, Hutchins DA, Ducklow HW (2000) Limitation of bacterial growth by dissolved organic matter and iron in the Southern Ocean. Appl Environ Microbiol 66:455-466

Cottrell MT, Kirchman DL (2000) Natural assemblages of marine proteobacteria and members of the CytophagaFlavobacter cluster consuming low- and high-molecularweight dissolved organic matter. Appl Environ Microbiol 66 (4):1692-1697

Eiler A, Langenheder S, Bertilsson S, Tranvik LJ (2003) Heterotrophic bacterial growth efficiency and community structure at different natural organic carbon concentrations. Appl Environ Microbiol 69:3701-3709

Foreman CM, Franchini P, Sinsabaugh RL (1998) The trophic dynamics of riverine bacterioplankton: relationships among substrate availability, ectoenzyme kinetics, and growth. Limnol Oceanogr 43:1344-1352

Frette $\mathrm{K}$, Johnsen $\mathrm{K}$, Jørgensen NOG, Nybroe O, Kroer N (2004) Functional characteristics of culturable bacterioplankton from marine and estuarine environments. Int Microbiol 7:219-227

Frontier S (1985) Diversity and structure in aquatic ecosystems. Oceanogr Mar Biol 23:253-312

Fry B, Hopkinson CS, Nolin A (1996) Long-term decomposition of DOC from experimental diatom blooms. Limnol Oceanogr 41:1344-1347

Gasol JM, del Giorgio PA (2000) Using flow cytometry for counting natural planktonic bacteria and understanding the structure of planktonic bacterial communities. Sci Mar 64:197-224

Grasshoff K, Ehrhardt M, Kremling K (1983) Methods of seawater analysis, 2nd edn. Verlag Chemie, Weinheim

Grossart HP, Simon M (2002) Bacterioplankton dynamics in the Gulf of Aqaba and the Northern Red Sea in early spring. Mar Ecol Prog Ser 239:263-276

Grover JP, Chrzanowski TH (2000) Seasonal patterns of substrate utilization by bacterioplankton: case studies in four temperate lakes of different latitudes. Aquat Microb Ecol 23:41-54 
Horner-Devine MC, Leibold MA, Smith VH, Bohannan BJM (2003) Bacterial diversity patterns along a gradient of primary productivity. Ecol Lett 6:613-622

Jensen LM (1983) Phytoplankton release of extracellular organic-carbon, molecular-weight composition, and bacterial assimilation. Mar Ecol Prog Ser 11:39-48

Jørgensen NOG, Kroer N, Coffin RB, Yang XH, Lee C (1993) Dissolved free amino-acids, combined amino-acids, and DNA as sources of carbon and nitrogen to marine-bacteria. Mar Ecol Prog Ser 98:135-148

Jørgensen NOG, Stepanaukas R, Pedersen AGU, Hansen M, Nybroe O (2003) Occurrence and degradation of peptidoglycan in aquatic environments. FEMS Microbiol Ecol 46: 269-280

Keil RG, Kirchman DL (1999) Utilization of dissolved protein and amino acids in the northern Sargasso Sea. Aquat Microb Ecol 18:293-300

Kirchman DL, Dittel AI, Findlay SEG, Fischer D (2004) Changes in bacterial activity and community structure response to dissolved organic matter in the Hudson River, New York. Aquat Microb Ecol 35:243-257

Konopka A, Oliver L, Turco RFJ (1998) The use of carbon substrate utilization patterns in environmental and ecological microbiology. Microb Ecol 35:103-115

Kramer GD, Pausz C, Herndl GJ (2005) Elemental composition of dissolved organic matter and bacterioplankton production in the Faroe-Shetland Channel (North Atlantic). Deep-Sea Res I 52:85-97

Lancelot C (1984) Extracellular release of small and large molecules by phytoplankton in the Southern Bight of the North-Sea. Estuar Coast Shelf Sci 18:65-77

Malmstrom RR, Cottrell MT, Elifantz H, Kirchman DL (2005) Biomass production and assimilation of dissolved organic matter by SAR11 bacteria in the Northwest Atlantic Ocean. Appl Environ Microbiol 71:2979-2986

Martínez J, Smith DC, Steward GF, Azam F (1996) Variability in ectohydrolytic enzyme activities of pelagic marine bacteria and its significance for substrate processing in the sea. Aquat Microb Ecol 10:223-230

Misic C, Povero P, Fabiano M (2002) Ectoenzymatic ratios in relation to particulate organic matter distribution (Ross Sea, Antarctica). Microb Ecol 44:224-234

Obernosterer I, Kraay G, De Ranitz E, Herndl GJ (1999) Concentrations of low molecular weight carboxylic acids and carbonyl compounds in the Aegean Sea (Eastern Mediterranean) and the turnover of pyruvate. Aquat Microb Ecol 20:147-156

Pérez MT, Pausz C, Herndl GJ (2003) Major shift in bacterioplankton utilization of enantiomeric amino acids between surface waters and the ocean's interior. Limnol Oceanogr 48:755-763

Porter K, Feig YS (1980) The use of DAPI for identifying and counting aquatic microflora. Limnol Oceanogr 25:943-948

Preston-Mafham J, Boddy L, Randerson PF (2002) Analysis of microbial community functional diversity using sole-carbon-source utilisation profiles - a critique. FEMS Microbiol Ecol 42:1-14

Pullin MJ, Bertilsson S, Goldstone JV, Voelker BM (2004) Effects of sunlight and hydroxyl radical on dissolved organic matter: bacterial growth efficiency and production of carboxylic acids and other substrates. Limnol Oceanogr 49:2011-2022

Riemann L, Azam F (2002) Widespread N-acetyl-D-glucosamine uptake among pelagic marine bacteria and its ecological implications. Appl Environ Microbiol 68:5554-5562

Rosenstock B, Zwisler W, Simon M (2005) Bacterial consump- tion of humic and non-humic low and high molecular weight DOM and the effect of solar irradiation on the turnover of labile DOM in the Southern Ocean. Microb Ecol 50:90-101

Sala MM, Güde H (2004) Ectoenzymatic activities and heterotrophic bacteria decomposing detritus. Arch Hydrobiol 160:289-303

Sala MM, Arin L, Balagué V, Felipe J, Guadayol Ò, Vaqué D (2005a) Functional diversity of bacterioplankton assemblages in western Antarctic seawaters during late spring. Mar Ecol Prog Ser 292:13-21

Sala MM, Balagué V, Pedrós-Alió C, Massana R, Felipe J, Arin L, Illoul H, Estrada M (2005b) Phylogenetic and functional diversity of bacterioplankton during Alexandrium spp blooms. FEMS Microbiol Ecol 54:257-267

Sala MM, Pinhassi J, Gasol JM (2006) Estimation of bacterial use of dissolved organic nitrogen (DON) compounds in aquatic ecosystems using Biolog plates. Aquat Microb Ecol 42:1-5

Sannigrahi P, Ingall ED, Benner R (2005) Cycling of dissolved and particulate organic matter at station Aloha: insights from C-13 NMR spectroscopy coupled with elemental, isotopic and molecular analyses. Deep-Sea Res I 52: 1429-1444

Schauer M, Massana R, Pedrós-Alió C (2000) Spatial differences in bacterioplankton composition along the Catalan coast (NW Mediterranean) assessed by molecular fingerprinting. FEMS Microbiol Ecol 33:51-59

Schauer M, Balagué V, Pedrós-Alió C, Massana R (2003) Seasonal changes in the taxonomic composition of bacterioplankton in a coastal oligotrophic system. Aquat Microb Ecol 31:163-174

Schultz GE, Ducklow HW (2000) Changes in bacterioplankton metabolic capabilities along a salinity gradient in the York River estuary, Virginia, USA. Aquat Microb Ecol 22: 163-174

Sinsabaugh RL, Foreman CM (2001) Activity profiles of bacterioplankton in a eutrophic river. Freshw Biol 46: 1239-1249

Tan TL (1997) Biolog metabolic fingerprints for clustering marine oligotrophic bacteria from polar regions. In: Insam $\mathrm{H}$, Rangger A (eds) Microbial communities. Functional versus structural approaches. Springer-Verlag, Berlin, p 161-170

Tan TL, Rüger HJ (1999) Enrichment, isolation, and Biolog metabolic fingerprints of oligotrophic bacteria from the Antarctic Ocean. Arch Hydrobiol Spec Iss Adv Limnol 54: $255-272$

Unanue M, Ayo B, Agis M, Slezak D, Herndl GJ, Iriberri J (1999) Ectoenzymatic activity and uptake of monomers in marine bacterioplankton described by a biphasic kinetic model. Microb Ecol 37:36-48

Vila M, Masó M (2005) Phytoplankton functional groups and harmful algal species in anthropogenically impacted waters of the NW Mediterranean Sea. Sci Mar 69(1):31-45

Vila M, Camp J, Garcés E, Masó M, Delgado M (2001) High resolution spatio-temporal detection of potentially harmful dinoflagellates in confined waters of the NW Mediterranean. J Plankton Res 23:497-514

Worm J, Gustavson K, Garde K, Borch NH, Sondergaard M (2001) Functional similarity of attached and free-living bacteria during freshwater phytoplankton blooms. Aquat Microb Ecol 25:103-111

Yentsch CS, Menzel DW (1963) A method for the determination of phytoplankton chlorophyll and phaeophytin by fluorescence. Deep-Sea Res 10:221-231

Submitted: March 6, 2006; Accepted: May 31, 2006

Proofs received from author(s): July 27, 2006 